\title{
Levels of Adherence and Associated Factors Among Children on ART Over Time in Northwest, Ethiopia: Evidence from a Multicenter Follow-Up Study [Corrigendum]
}

GebreEyesus F, Mitku D, Tarekegn T, et al. HIV AIDS (Auckl). 2021;13:829-838.

The authors have advised there are errors in the author list on page 829. The author names "Fisha GebreEyesus", "Tadesse Tarekegn", "Bogale Temere", "Tamene Terefe", "Dejen Feleke", "Nega Baye", "Fitalew Admasu",
"Tewachew Liyeh", "Melkamu Jimma" and "Ermias Chanie" should read "Fisha Alebel GebreEyesus", "Tadesse Tsehay Tarekegn", "Bogale Chekole Temere", "Tamene Fetene Terefe", "Dejen Getaneh Feleke", "Nega Dagnew Baye", "Fitalew Tadele Admasu", "Tewachew Muche Liyeh", "Melkamu Senbeta Jimma" and "Ermias Sisay Chanie", respectively. control viral spread. The manuscript management system is completely online and includes a very quick and fair peer-review system, which is all easy to use. Visit http://www.dovepress.com/testimonials.php to read real quotes from published authors. 